Daria Matek, Piotr Kudaj ${ }^{1}$

\title{
Dobre praktyki estońskiej e-administracji. Rekomendacje dla Polski
}

\section{Wstęp}

E-administracja definiowana jest jako wykorzystanie przez agencje rządowe technologii informacyjnych, które mają zdolność do przekształcenia stosunków z obywatelami, przedsiębiorstwami oraz innymi podmiotami pozostającymi w pewnych stosunkach $\mathrm{z}$ rządem. Technologie te mogą zwiększyć efektywność w zakresie dostarczania usług publicznych dla obywateli, relacji z biznesem i przemysłem oraz zarządzania rządu. E-administracja ma na celu stworzenie warunków interakcji między rządem a obywatelami, rządem a biznesem przedsiębiorstw i czynienie relacji między agencjami bardziej przyjaznymi, wygodnymi, przejrzystymi i niedrogimi ${ }^{2}$. Do najważniejszych korzyści należą:

- lepsza koordynacja polityki UE i prawodawstwa z potencjalnym przyłączeniem się rządu,

- bardziej wydajne i efektywne wykorzystanie zasobów w czasie, w momencie gdy nie ma zwiększonej presji na rząd, aby ograniczył swoje wydatki i zmniejszył obciążenia podatkowe nałożone na obywateli i przedsiębiorstwa,

- stworzenie potencjału umożliwiającego obywatelom bardziej skuteczne, przejrzyste ilościowe i jakościowe kontrolowanie rządu³.

Z raportu Przedstawicielstwa Komisji Europejskiej w Polsce z 28 maja 2013 r. wynika, że Europejczycy bardzo chętnie wykorzystują e-administrację, a także chcieliby jej rozbudowania. Szczególnie pomocna jest przy rozliczeniach podatkowych, rejestrowaniu firm czy składaniu podań w urzędach. Prawie połowa, bo $46 \%$ obywateli, posługuje się Internetem, aby znaleźć pracę, złożyć deklarację podatkową, zgłosić narodziny dziecka czy skorzystać z biblioteki publicznej. Wśród zalet korzystania z tych usług

1 Daria Małek, Piotr Kudaj, Uniwersytet Pedagogiczny im. Komisji Edukacji Narodowej w Krakowie.

2 P.G. Nixon, V.N. Koutrakou, E-government in Europe. Re-booting the state, Routledge Canada 2007, s. 20.

3 Ibidem, s. 21. 
wymieniają oszczędność czasu i pieniędzy oraz elastyczność. Jednakże poziom usług świadczonych przez elektroniczną administrację nie spełnia w pełni potrzeb obywateli, ponieważ bardziej satysfakcjonuje ich funkcjonowanie bankowości internetowej czy możliwość robienia zakupów za pomocą Internetu 4 .

Republika Estońska, mimo iż jest niewielkim państwem, mającym ponad 1,3 $\mathrm{mln}^{5}$ populacji, znajduje się w ścisłej europejskiej czołówce w dziedzinie internetyzacji, przy czym ponad połowa obywateli posiada stały dostęp do Internetu oraz posługuje się podpisem elektronicznym ${ }^{6}$. Dodatkowo istnieje tam możliwość głosowania przez Internet, elektroniczne dowody osobiste umożliwiające korzystanie z usług na terenie całego kraju oraz specjalny system, któremu podlegają szkoły ${ }^{7}$. Natomiast w Polsce poziom e-usług jest niższy niż w Rosji czy Kazachstanie.

Pomimo wieloletnich starań i ciągłego finansowania stan polskiej e-administracji znacznie odbiega od większości krajów Unii Europejskiej. Oferowane usługi nie są spójne, a ich wykorzystanie jest marginalne. $Z$ tego względu głównym założeniem artykułu jest pokazanie, w jaki sposób Polska mogłaby wykorzystać doświadczenie Estonii w zakresie e-administracji, tym bardziej że Estonia chętnie dzieli się swoimi doświadczeniami.

\section{Stan e-administracji w Estonii}

\subsection{Początki E-stonii}

Pomysł na rozwój technologiiinformacyjnejw Estoniizrodziłsięw 1991 r., po odzyskaniu niepodległości po 50 latach zależności od ZSRR. Dążono wówczas do ograniczenia kosztów zarządzania państwem oraz stworzenia miejsc pracy dla mieszkańców ${ }^{8}$. E-administracyjną reformę Estonia rozpoczęła od programów cyfryzacji szkół, następnie wprowadzając elektroniczny dowód osobisty oraz stwarzając możliwość głosowania w wyborach za pomocą Internetu9. Rozwój e-government oraz technologii informacyjnych i komunikacyjnych miał podłoże w szeregu regulacji prawnych:

4 Komisja Europejska Polska, E-administracja jest OK, http://ec.europa.eu/polska/ news/130528_e_administracja_pl.htm (dostęp: 5.07.2016).

5 Statistical Office of Estonia, http://www.stat.ee/population (dostęp: 27.08.2016).

6 M. Chlewicki, A. Kędzierska, M. Oranowski, Elektroniczna administracja w Estonii, http://www.bibliotekacyfrowa.pl/Content/34511/016.pdf (dostęp: 27.08.2016).

7 Estonia dzieli się swoim e-doświadczeniem, http://newsrm.tv/komunikat-pr/estonia-dzieli-sie-swoim-e-doswiadczeniem/ (dostęp: 29.08.2016).

8 A. Dzierżek, Cud technologiczny na pótnocy Europy. Jak Estonia stała się internetowa potega i państwem bez granic, http://forsal.pl/artykuly/865849,cud-technologiczny-na-polnocy-europy-jak-estonia-stala-sie-internetowa-potega-i-panstwem-bezgranic.html (dostęp: 29.08.2016).

9 K. Olejak, E-państwo po estońsku, http://jagiellonski24.pl/2016/02/02/e-panstwo-po-estonsku/ (dostęp: 29.08.2016). 
prawo ochrony prywatnych danych, prawo dotyczące baz danych, fundamenty systemów informatycznych, prawo dotyczące dokumentów identyfikacyjnych oraz podpisu elektronicznego, ustanowienie podstaw polityki informacyjnej. Przywiązywanie dużej wagi do związanych z technologią regulacji prawnych było ważnym czynnikiem stojącym za sukcesem Estonii. Innymi istotnymi dla rozwoju e-governance prawami były: ustawa o podpisie elektronicznym, ustawa o informacji publicznej, ustawa o ochronie danych osobowych, podstawy unifikujące dla procedur zarządzania dokumentami i ustawa o archiwach ${ }^{10}$.

W przeciągu 20 lat Estonia zdołała stworzyć system e-państwa, który aktualnie stawiany jest innym europejskim krajom za przykład. Warto podkreślić, iż w Estonii sukces ten nie wiąże się z wysokimi wydatkami finansowymi. Koszt połączenia poszczególnych serwerów urzędów w jedną, sprawnie działającą całość wyniósł 50-60 mln euro. W tej kwocie mieszczą się koszty stworzenia, utrzymania oraz inwestycji. Estonia nie mogła sobie pozwolić (ze względu na zbyt duże koszty) na zbudowanie od podstaw centralnego państwowego serwera - x-Road, dlatego też zdecydowała się na inne rozwiązanie. Opracowana przez Estonian Information System's Authority platforma wymiany danych x-Road jest narzędziem krytycznym, które łączy wszystkie zdecentralizowane komponenty z odrębnych systemów ${ }^{11}$. Dzięki niemu większość urzędowych spraw obywatele mogą załatwić bez wychodzenia $\mathrm{z}$ domu, a jedynym potrzebnym narzędziem jest komputer z dostępem do Internetu. Od 2000 r. prawo obywatela do dostępu do Internetu jest zagwarantowane konstytucyjnie. Estończycy mogą korzystać i korzystają z bogatego pakietu e-usług, w skład którego wchodzą m.in. składanie zeznań podatkowych czy wystawianie pacjentom elektronicznych recept przez lekarzy (które ostatecznie trafiają do farmaceutów, a pacjent może je odebrać w dowolnej aptece po uprzednim okazaniu elektronicznego dowodu osobistego $)^{12}$. Warto zaznaczyć, że to nie sama władza osiągnęła ten sukces, ponieważ obywatele też mieli w tym swój udział. W 2001 r. dzięki stronie „Dziś zdecyduj” (Täna Otsustan Mina), będącej jedną wielką bazą danych, Estończycy mogli przedstawiać swoje pomysły i uwagi dotyczące projektów lub poprawek ustaw ${ }^{13}$.

\subsection{ID-kaart}

Największym przełomem w budowaniu e-państwa okazało się wprowadzenie w 2007 r. obowiązkowych elektronicznych dowodów osobistych, które otwierają obywatelom drzwi do szerokiego pakietu e-usług. Rząd

10 I. Pappel, E. Vanker, Przeglad projektów e-Government w Estonii, http://egov 2.eu/ $\mathrm{pl} /$ knowledge-base/przeglad-projektow-e-government-w-estonii/ (dostęp: 29.08.2016).

11 Ibidem.

12 A. Dzierżek, Cud technologiczny...

13 K. Olejak, E-państwo... 
przyjął plan wdrożenia chipowych dowodów osobistych w maju $2000 \mathrm{r}$., a od stycznia 2002 r. do maja 2006 r. taki dowód posiadało 850 tys. obywateli ${ }^{14}$. E-dowód przyznawany jest automatycznie każdemu obywatelowi Estonii, który ukończył 15. rok życia, a obecnie elektronicznych dowodów używa ponad $90 \%$ Estończyków ${ }^{15}$. Przy pomocy jednej plastikowej karty $\mathrm{z}$ chipem można załatwić wiele ważnych urzędowych spraw on-line. $\mathrm{Na}$ karcie, oprócz imienia i nazwiska znajdują się: klucze kryptograficzne, które umożliwiają wykonanie elektronicznego podpisu (ustawa o podpisach elektronicznych zrównuje go $\mathrm{z}$ podpisem własnoręcznym ${ }^{16}$ ), e-recepta, czyli karta zdrowia, na której znajdują się wszystkie dane o pacjencie wraz z przepisywanymi lekami (od 2009 r. recepty wystawiane są tylko i wyłącznie $\mathrm{w}$ formie elektronicznej. W tym systemie funkcjonują wszystkie estońskie szpitale), bilet komunikacji miejskiej, prawo jazdy czy legitymacja studencka ${ }^{17}$. ID-kaart obsługuje już ponad 4 tys. usług ${ }^{18}$. Dowód wykorzystywany jest podczas głosowania $\mathrm{w}$ wyborach, $\mathrm{w}$ celu uwierzytelnienia głosu, a także podczas zakładania firmy. Możliwość prowadzenia księgowości przez Internet powoduje, iż Estonia plasuje się na drugim miejscu (wyprzedza ją tylko USA) pod względem posiadania start-upów per capita. Jednym $\mathrm{z}$ nich jest GrabCAD - chmura bezpłatnie użytkowana przez inżynierów zajmujących się projektowaniem wspomaganym komputerowo, stwarzająca kanał komunikacyjny ${ }^{19}$.

Estonia podjęła starania mające na celu umożliwienie wykorzystania e-usług obywatelom innych państw. 21 października 2014 r. parlament przyjął ustawę, na mocy której ID-kaarty będzie można zaoferować obywatelom innych krajów (program nosi nazwę e-Residency). Nie jest to tożsame $\mathrm{z}$ nadaniem obywatelstwa estońskiego, jednak program ten daje możliwość korzystania z szerokiej gamy e-usług. Taki dokument może otrzymać osoba, która ukończyła 18 lat. W tym celu musi udać się na posterunek estońskiej straży granicznej, gdzie zostaną pobrane odciski palców oraz zrobione zdjęcie. Koszt operacji wynosi 50 euro, a czas realizacji to dwa tygodnie, $\mathrm{w}$ trakcie których służby sprawdzają tożsamość zainteresowanego. Nadanie takiej karty jest tożsame z otrzymaniem kluczy i certyfikatów umożliwiających zalogowanie się do usług elektronicznych świadczonych zarówno przez sektor prywatny, jak i publiczny. Daje to także możliwość korzystania z elektronicznego podpisu, który jest wiążący we wszystkich państwach Unii Europejskiej, a także w umowach cywilnych we wszystkich krajach na świecie. Władze Estonii nie ukrywają, iż celem takich rozwiązań jest przyciągnięcie przedsiębiorców, wierzą, że

14 M. Chlewicki, A. Kędzierska, M. Oranowski, Elektroniczna...

15 A. Dzierżek, Cud technologiczny...

16 M. Chlewicki, A. Kędzierska, M. Oranowski, Elektroniczna...

17 K. Olejak, E-państwo...

18 A. Golański, E-stonia...

19 K. Olejak, E-państwo... 
przejrzysty system podatkowy i rozwinięta infrastruktura internetowa to wystarczająca zachęta dla inwestorów, dzięki którym firmy zyskają więcej klientów, a sama Estonia więcej kapitału ${ }^{20}$. Aktualnie wydano już ponad 500 e-dowodów na zasadzie programu e-Residency, a szacuje się, że do 2025 r. może ich funkcjonować $10 \mathrm{mln}^{21}$.

\subsection{E-głosowanie i cyberbezpieczeństwo}

W 2005 r. w Estonii dopuszczono możliwość oddania głosu przez Internet w wyborach samorządowych ${ }^{22}$. Do tej pory $z$ takiej formy głosowania Estończycy mieli okazję skorzystać już osiem razy: po trzy razy w wyborach samorządowych i parlamentarnych oraz dwa razy w eurowyborach ${ }^{23}$. Wykorzystując tę formę, głosy można oddawać przez 7 dni, a termin ich oddawania mija 4 dni przed wyborami ${ }^{24}$. W tym czasie e-wyborcy mogą oddać dowolną liczbę głosów, a liczy się ten, który został oddany jako ostatni. Istnieje także możliwość anulowania oddanego w e-wyborach głosu poprzez ponowne zagłosowanie w lokalu wyborczym ${ }^{25}$. Aby móc skorzystać $\mathrm{z}$ tej funkcjonalności, potrzebny jest komputer $\mathrm{z}$ dostępem do Internetu, ID-kaart oraz oprogramowanie do głosowania. Przy użyciu elektronicznego dowodu można zalogować się do specjalnej aplikacji, następnie wybrać kandydata, a wszystko potwierdzone zostaje podpisem elektronicznym, który również znajduje się na ID-kaarcie. Taki głos zostaje zaszyfrowany i przesłany na serwer Komisji Wyborczej ${ }^{26}$.

Wykres 1 obrazuje tendencje wzrostowe w zakresie korzystania z elektronicznego głosowania w wyborach. W 2005 r. z głosowania przez Internet skorzystało zaledwie 1,9\% uprawnionych do głosowania ( $\mathrm{tj}$. oddano 9287 ważnych głosów), z kolei w 2015 r. liczba ta wzrosła o 28,6\% (oddano 176329 ważnych głosów, tj. 30,5\%). Estonia od czasu wprowadzenia możliwości głosowania przez Internet odnotowała wzrost frekwencji wyborczej, a także mniejszy odsetek głosów nieważnych. Na przykład frekwencja podczas wyborów parlamentarnych w 2015 r. wyniosła 64,2\% ${ }^{27}$ (dla porówna-

20 A. Golański, E-stonia...

21 A. Dzierżek, Cud technologiczny...

22 M. Kutyłowski, F. Zagórski, Głosowanie elektroniczne. Aktualny stan wiedzy, http://klub.platforma.org/files/raport.pdf (dostęp: 1.09.2016).

23 K. Popławski, I-wybory. E-wybory. Wybory on line. A gdybyśmy uważniej spojrzeli na Estonię?, https://wszystkoconajwazniejsze.pl/kazimierz-poplawski-i-wybory-e-wybory-wybory-on-line-a-gdybysmy-uwazniej-spojrzeli-na-estonie/ (dostęp: 1.09.2016).

24 M. Kutyłowski, F. Zagórski, Głosowanie...

25 K. Popławski, $I$-wybory...

26 Ibidem.

27 Riigikogu valimised 2015, http://rk2015.vvk.ee/participation.html (dostęp: 1.09.2016). 
nia w 1999 r. było to 57,5\%). Porównując okres między rokiem 1999 a 2011, widzimy, że liczba nieważnych głosów zmniejszyła się o dwie trzecie ${ }^{28}$.

Wykres 1. Liczba głosujących w estońskich wyborach od 2005 r. (w tysiącach)

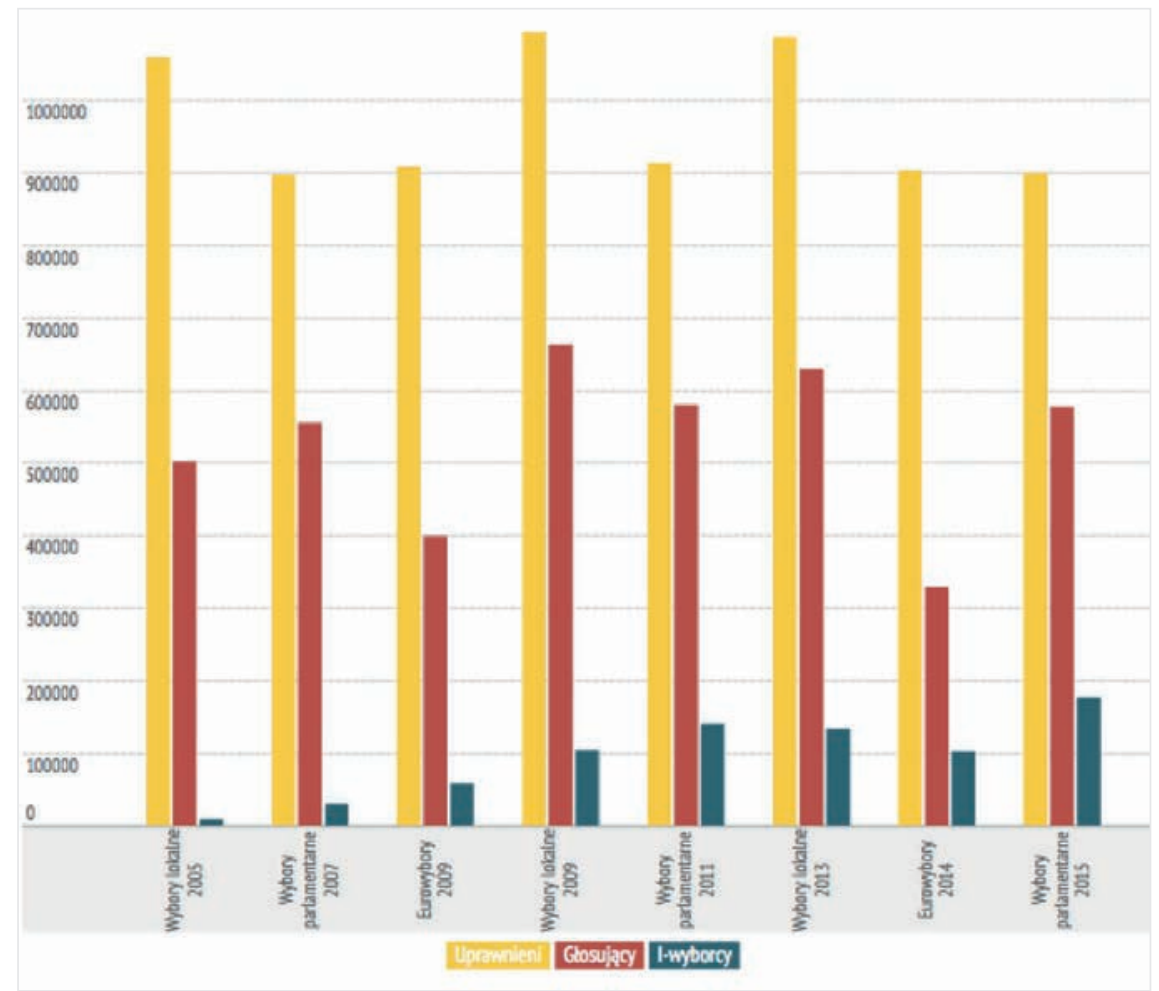

Źródło: K. Popławski, I-wybory. E-wybory. Wybory on line...

W 2013 r. grupie informatyków, którzy testowali system, udało się do niego włamać i niezauważalnie zmienić wyniki wyborów. Z kolei w 2007 r. doszło do ataku hakerów na strony rządowe, banki i media ${ }^{29}$. Z tego względu władze opracowały i wdrożyły w 2014 r. jedną z pierwszych na świecie narodowych strategii cyberbezpieczeństwa. W Tallinie swoją siedzibę ma jednosta NATO ds. cyberbezpieczeństwa. Każdy Estończyk, który korzysta z e-usług, posiada wgląd do informacji na temat tego, kto i kiedy miał dostęp do jego danych ${ }^{30}$.

28 Estonia dzieli się...

29 K. Olejak, E-państwo...

30 Ibidem. 


\section{Stan e-administracji w Polsce}

\subsection{Początki e-administracji w Polsce}

Polska stawiała pierwsze kroki w kierunku informatyzacji społeczeństwa w ostatniej dekadzie ubiegłego tysiąclecia, która obfitowała w wiele publicznych dyskusji i konferencji poświęconych tej tematyce. Za punkt startowy całego procesu można uznać raport pt. Propozycja strategii rozwoju informatyki i jej zastosowań w Rzeczypospolitej Polskiej, sporządzony przez Polskie Towarzystwo Informatyczne w 1991 r. Pomimo żywego zainteresowania nową płaszczyzną długo nie ujawniano żadnych dokumentów prawnych, które mogłyby umocować $\mathrm{i}$ wesprzeć $\mathrm{w}$ dalszym rozwoju pomysły na scyfryzowany naród ${ }^{31}$.

Polska musiała czekać kilka lat do czasu, kiedy Sejm RP w 2000 r. podjął uchwałę w zakresie budowania podstaw społeczeństwa informacyjnego, przy czym wyznaczono również cele i kierunki społeczeństwa informacyjnego w Polsce. Jednakże pierwsze faktyczne działania dotyczące e-administracji datuje się na $2001 \mathrm{r}$. Uchwalono wtedy dwie szczególne ustawy: o dostępie do informacji publicznej oraz o podpisie elektronicznym. Następnym wyraźnym krokiem $\mathrm{w}$ informatyzacji administracji był plan inspirowany europejskim rozwiązaniem eEurope - an information society for all, który zakładał zbudowanie światowego społeczeństwa informacyjnego na fundamencie społeczeństwa europejskiego ${ }^{32}$. I tak ePolska skupiała się na sześciu głównych celach ${ }^{33}$ :

1) rozwój infrastruktury informatycznej,

2) powszechny, tańszy, szybszy i bezpieczny Internet,

3) inwestowanie w ludzi i umiejętności,

4) stymulowanie lepszego wykorzystania technologii informacyjnych,

5) teleinformatyka na obszarach wiejskich,

6) rozwój radiofonii i telewizji cyfrowej.

Powyższy plan działań miał zostać zrealizowany na przestrzeni lat 2001-2006, aby doprowadzić do współtworzenia oraz włączenia Polski do globalnego społeczeństwa informacyjnego ${ }^{34}$.

31 Polska $w$ drodze do społeczeństwa informacyjnego, http://e-administracja. net/e-administracja/polska-w-drodze-do-spoleczenstwa-informacyjnego (dostęp: 1.09.2016).

32 B. Kozłowska, Miejsce dla obywateli: e-administracja, Fundacja Rozwoju Społeczeństwa Informatycznego, Warszawa 2010, http://programrozwojubibliotek.org/wp-content/uploads/2015/07/Miejsce_dla_obywateli_e_administracja.pdf (dostęp: 1.09.2016).

33 ePolska. Plan działań na rzecz rozwoju społeczeństwa informacyjnego w Polsce na lata 2001-2006, http://kbn.icm.edu.pl/cele/epolska.doc (dostęp: 5.09.2016).

34 Ibidem, s. 8. 


\section{2. ePolska w eEuropie}

Niewątpliwie istotnym wydarzeniem w nowożytnej historii Polski jest akcesja do Unii Europejskiej ${ }^{35}$, za którą w referendum ogólnokrajowym opowiedziało się 77,45\% obywateli ${ }^{36}$. Polska dołączyła do UE wraz z kilkoma innymi państwami, m.in. Estoniąa ${ }^{37}$. Mimo iż zaczęto pracować nad rozwiązaniami w zakresie cyfryzacji państwa i rozwoju w e-administracji w tym samym czasie, rozwiązania estońskie od samego początku były skuteczniejsze, na co wskazują pierwsze raporty Komisji Europejskiej. W początkowych latach członkostwa Polski w Unii Europejskiej usługi, które miały zostawać informatyzowane, nie spełniały nawet pierwszego stopnia rozwoju e-government ${ }^{38}$, a cyfrowa dojrzałość publicznych serwisów internetowych została oszacowana na $36 \%{ }^{39}$. Takie wyniki sprawiały, że Polska zajmowała najniższe lub jedne $\mathrm{z}$ najniższych miejsc pośród państw Unii Europejskiej we wszelkich porównaniach, podczas gdy Estonia znajdowała się po drugiej stronie zestawienia ${ }^{40}$.

W miarę upływu lat można mówić o poprawie sytuacji w Polsce. W badaniach i raportach pochodzących z przełomu 2007 i 2008 r. widać, że strategie i rozwiązania podejmowane w celu dalszego cyfryzowania społeczeństwa przyniosły pewne efekty. Można było mówić o rozwoju na niemal trzecim stopniu w pięciostopniowej skali ${ }^{41}$. Pomimo to Polska wciąż znajdowała się na końcu w zestawieniu efektywności wprowadzania e-government $\mathrm{i}$ była średnio o jeden stopień niżej w rozwoju e-usług w porównaniu do pozostałych państw Unii Europejskiej ${ }^{42}$.

Raport e-Government Survey z 2014 r. nie pozostawia wątpliwości, że e-administracja w Polsce jest wciąż na alarmująco niskim poziomie. Pomimo upływu lat i finansowania coraz to nowszych rozwiązań Polska wypada we wspomnianym raporcie gorzej niż Rosja, a nawet Kazachstan. Nieznacznie wyprzedzamy w rankingu takie państwa jak Andora, Czarno-

35 Polska $w$ Unii Europejskiej, https://europa.eu/european-union/about-eu/countries/member-countries/poland_pl (dostęp: 8.09.2016).

36 Obwieszczenie Państwowej Komisji Wyborczej o wyniku ogólnokrajowego referendum w sprawie wyrażenia zgody na ratyfikację Traktatu dotyczącego przystąpienia Rzeczypospolitej Polskiej do Unii Europejskiej (Dz. U. z 2003 r. Nr 103, poz. 953).

37 Estonia w Unii Europejskiej, https://europa.eu/european-union/about-eu/countries/member-countries/estonia_pl (dostęp: 9.09.2016).

38 Czterostopniowa skala oceniania zaawansowania rozwoju e-usług, gdzie pierwsza to możliwość wyszukiwania informacji na stronach internetowych dotyczących urzędów i usług przez nie świadczonych.

39 D. Grodzka, E-administracja w Polsce, http://orka.sejm.gov.pl/WydBAS.nsf/0/5B3DCD2263623C69C125730E003F93CA/\$file/infos_018.pdf(dostęp: 9.09.2016).

40 Ibidem.

41 Pierwsze badania wykorzystywały czterostopniową skalę do czasu, kiedy w raporcie z 2007 r. przedstawiono skalę pięciostopniową.

42 D. Grodzka, E-governemnt... 
góra i Kolumbia. Do 2015 r. państwowe systemy informatyczne kosztowały 2,9 mld zł i wymagają dalszego finansowania ${ }^{43}$.

Wykres 2. Wydatki na e-administrację w Polsce (kwoty w milionach złotych poniesione od momentu uruchomienia każdego z systemów do 2015 r.)

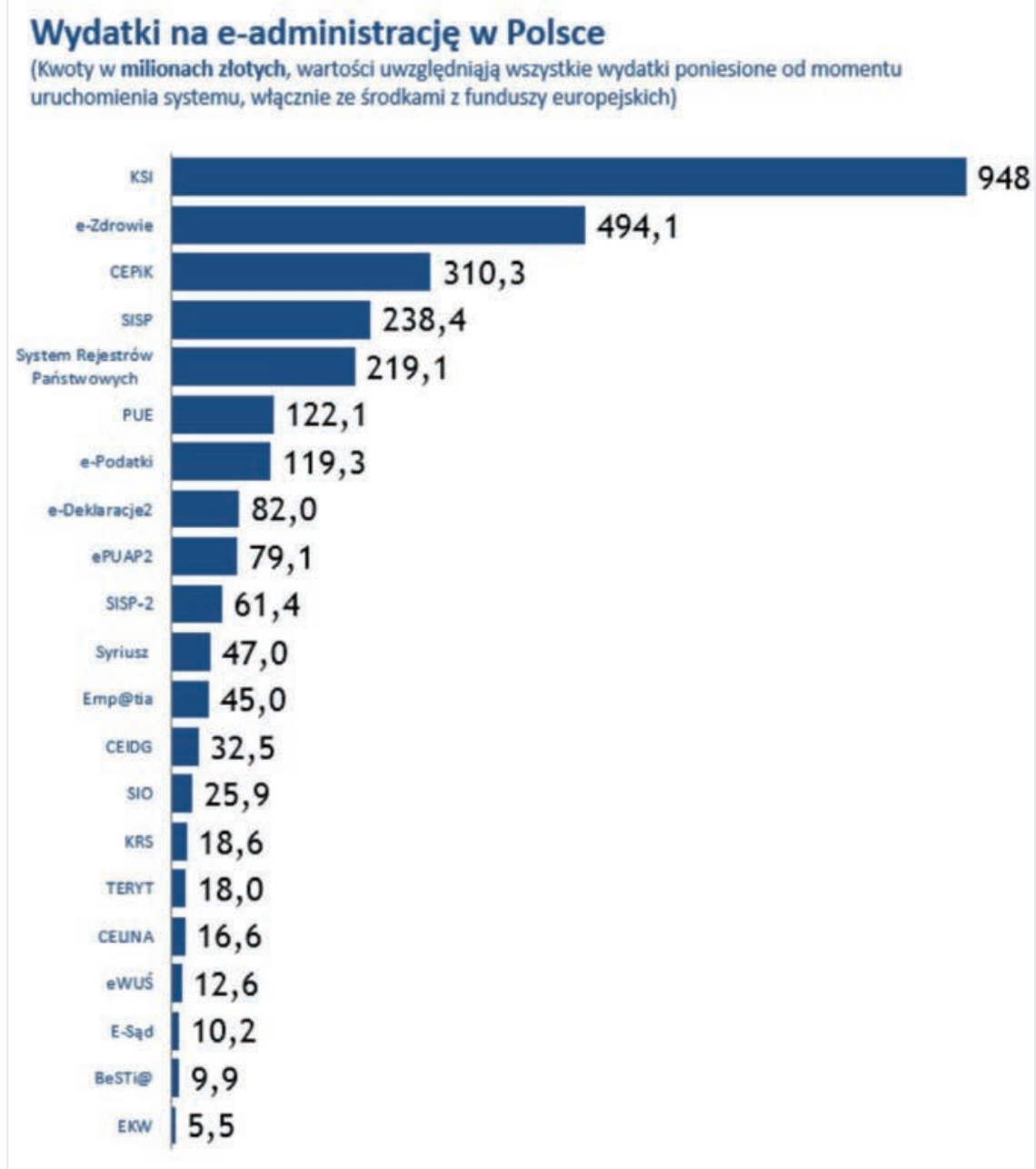

Źródło: M. Ratajczak, E-administracja w Polsce...

Wykres 2 przedstawia wydatki na e-administrację w Polsce w rozbiciu na pojedyncze systemy. Zauważalne są dysproporcje w finansowaniu poszczególnych rozwiązań. Najdroższy z nich, czyli obsługiwany przez Za-

43 M. Ratajczak, E-administracje w Polsce kosztowała miliardy złotych. I wciąż jest gorsza niż w Rosji i Kazachstanie, http://news.money.pl/artykul/e-administracja-w-polsce-kosztowala-miliardy,48,0,1755184.html (dostęp: 10.09.2016). 
kład Ubezpieczeń Społecznych KSI ${ }^{44}$ pochłania gigantyczne kwoty, jednak $\mathrm{z}$ drugiej strony jest to jedno $\mathrm{z}$ najbardziej zaawansowanych technologicznie rozwiązań informatycznych w Europie ${ }^{45}$. W niespełna rok od jego uruchomienia miał już bazę ponad 800 tys. użytkowników ${ }^{46}$. $Z$ drugiej strony na przykładzie $\mathrm{CEiDG}^{47}$ widać, że nie trzeba dużych nakładów finansowych, aby osiągać dobre wyniki. Dzięki temu systemowi udało się osiągnąć cel „zero okienka i formalności” w zakresie rozpoczynania działalności gospodarczej. Od momentu jego powstania przyjęto ponad 4,5 mln wniosków i obsłużono ponad 3,5 mln wpisów przedsiębiorców ${ }^{48}$. Warto jednak zaznaczyć, że w tym czasie Estonia zdołała wybudować sprawnie funkcjonujący system, wykorzystując zaledwie ułamek budżetu, jaki przeznacza na to Polska ${ }^{49}$.

Najwyższa Izba Kontroli również zainteresowała się jakością oferowanych i udostępnianych e-usług, promocją oraz sprawnością we wdrażaniu nowych rozwiązań w tym zakresie. W 2015 r. z własnej inicjatywy NIK przeprowadziła kontrolę $\mathrm{w}$ wybranych urzędach marszałkowskich, urzędach gmin miejskich i miejsko-wiejskich oraz miast na prawach powiatu. Najwyższa Izba Kontroli wykazuje, że pomimo znacznego finansowania e-administracja wzbudza niewielkie zainteresowanie, a w konsekwencji nie jest wykorzystywana. Przykładowo zauważono ten problem w obrębie portalu Wrota Mazowsza, na którym uruchomiono 1128 e-usług, a na przestrzeni 8 miesięcy zrealizowano tylko 169 usług, z których skorzystało 78 osób. Pomimo popularyzacji i rosnącego zainteresowania Polaków rozwiązaniami z wykorzystaniem Internetu zaledwie $1 \%$ dorosłych obywateli posiada zaufany profil umożliwiający korzystanie z usług e-urzędu. Dane Eurostatu wskazują, że tylko co czwarty Polak kontaktuje się z administracją publiczną w cyfrowy sposób. Jednocześnie w innych krajach jest to średnio połowa obywateli, a w niektórych państwach Unii Europejskiej zainteresowanie takimi rozwiązaniami wynosi ponad 80\% Pośród badanych podmiotów zauważa się dysproporcje zarówno w wykorzystaniu, jak i ilości dostępnych usług. Niektóre z nich świadczyły zaledwie jedną, wymaganą przez prawo usługę, czyli Elektroniczną Skrzynkę Podawczą, kiedy inne w swojej ofercie miały ich ponad $300^{50}$.

44 KSI - Kompleksowy System Informatyczny Zakładu Ubezpieczeń Społecznych.

45 M. Ratajczak, E-administracja...

46 K. Szubert, E-administracja w Polsce: korzyści i koszty, http://www.egospodarka. pl/117769,E-administracja-w-Polsce-korzysci-i-koszty,1,39,1.html (dostęp: 10.09.2016).

47 CEiDG - Centralna Ewidencja i Informacja o Działalności Gospodarczej.

48 M. Ratajczak, E-administracja...

49 K. Olejak, E-państwo...

50 Najwyższa Izba Kontroli, Świadczenie usług publicznych $w$ formie elektronicznej na przykładzie wybranych jednostek samorzadu terytorialnego - Informacja o wynikach kontroli. 
NIK wykazała, że we wszystkich oprócz dwóch urzędów objętych postępowaniem kontrolnym głównym sposobem dokumentowania spraw był tryb papierowy. Skalę tego problemu przedstawia wykres $3^{51}$ :

Wykres 3. Udział poszczególnych form korespondencji w komunikacji z urzędem

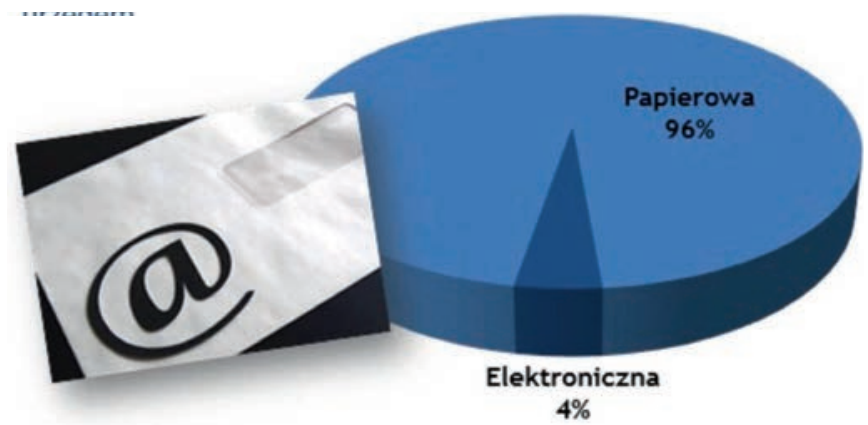

Źródło: M. Ratajczak, E-administracja w Polsce...

Najwyższa Izba Kontroli wymienia czynniki odpowiadające za niewielkie zainteresowanie obywateli udostępnianymi cyfrowymi usługami urzędów ${ }^{52}$. Należą do nich:

- bardzo niska liczba utworzonych zaufanych profili umożliwiających korzystanie z e-usług wymagających podpisu elektronicznego,

- przepisy obligujące do osobistego stawiennictwa $\mathrm{w}$ celu przedstawiania dokumentów w większości czynności urzędowych,

- nieustanny brak zaufania do nowych rozwiązań obywateli, którzy wolą załatwiać swoje sprawy osobiście,

- niedostateczna promocja e-usług.

W związku z powyższymi ocenami stanu e-administracji w Polsce na przestrzeni lat nasuwa się następujące pytanie: jakie dobre praktyki i rozwiązania Polska mogłaby przyjąć, aby poprawić jakość i zwiększyć dostępność oferowanych e-usług?

\section{Rekomendacje dla polskiej e-administracji}

\section{1. pl.ID}

W przeszłości najważniejszy i podstawowy dokument każdego obywatela miał postać 20 -stronicowej książeczki, która zawierała wszystkie podstawowe informacje o posiadaczu m.in. stan cywilny, zawód czy miejsce zatrudnienia. Po wielu latach, w 2001 r. dowody osobiste w Polsce doczekały

51 M. Ratajczak, E-administracja...

52 NIK o uslugach elektronicznych $w$ administracji publicznej,https://www.nik.gov. $\mathrm{pl} /$ aktualnosci/nik-o-uslugach-elektronicznych-w-administracji-publicznej.html (dostęp: 10.09.2016). 
się rewolucji. Przede wszystkim doszło do zmiany formy i formatu całego dokumentu i od tego momentu była to twarda karta wykonana z poliwęglanu, wielkością odpowiadająca karcie kredytowej. Wprowadzenie nowego dowodu osobistego miało przede wszystkim podnieść poziom zabezpieczeń samego dokumentu ${ }^{53}$. W 2015 r. światło dzienne ujrzało kolejne, najnowsze wydanie dowodu osobistego, w którym ponownie zadbano o wysoki poziom zabezpieczeń. Poza tym $\mathrm{z}$ dokumentu usunięto adres stałego zameldowania, co zostało uargumentowane brakiem konieczności wymiany dowodu osobistego przy zmianie miejsca zamieszkania ${ }^{54}$. Jednakże takie tłumaczenie nie przekonało wielu podmiotów i obywateli, którzy zaczęli się zastanawiać nad zasadnością takiego rozwiązania ${ }^{55}$.

Dowód osobisty jest podstawowym dokumentem, który posiada każdy pełnoletni obywatel państwa. Dlatego Polska powinna wykorzystać doświadczenia Estonii w zakresie wprowadzania elektronicznych dowodów osobistych. Estonia zdawała sobie sprawę z zalet wprowadzenia ID-kaart i w 2000 r. postanowiła na ich podstawie zbudować solidny fundament pod kompleksowe cyfrowe państwo ${ }^{56}$. Polska zauważa potrzebę wprowadzenia podobnych rozwiązań na własnym terytorium i pracuje nad tym od dłuższego czasu, jednakże cała procedura wydaje się przedłużać o kolejne lata ${ }^{57}$. Do tej pory podjęto już kilka prób wprowadzania e-dowodów, a ich początki sięgają 2010 r. Zaprezentowana w 2015 r. najświeższa generacja dowodów miała już być tą cyfrową, niestety ponownie odłożono w czasie wprowadzenie długo wyczekiwanych dokumentów. Aktualny i prawdopodobnie najbardziej realny termin na wprowadzenie cyfrowych dowodów to 31 marca 2019 r., co wynika z przepisów UE oraz z faktu, że niedotrzymanie tego terminu doprowadzi do anulowania finansowania $z$ UE $w$ wysokości $297 \mathrm{mln}$ zł na projekt pl.ID ${ }^{58}$.

Polskie e-dowody zainspirowane estońskimi ID-kaartami dodatkowo mogłyby stać się wielofunkcyjnym narzędziem każdego obywatela ${ }^{59}$ :

53 Ibidem.

54 Nowy dowód osobisty - PWPW przygotowała 27 tys. Plakatów informacyjnych, https://mswia.gov.pl/pl/aktualnosci/12966, Nowy-dowod-osobisty-PWPW-przygotowala-27-tys-plakatow-informacyjnych.html (dostęp: 10.09.2016).

55 K. Sudaj, O kłopotach $z$ nowym dowodem osobistym bez adresu zameldowania, http://www.bankier.pl/wiadomosc/O-klopotach-z-nowym-dowodem-osobistym-bez-adresu-zameldowania-7239103.html (dostęp: 10.09.2016).

56 M. Chlewicki, A. Kędzierska, M. Oranowski, Elektroniczna...

57 M. Maj, Elektroniczny dowód osobisty - nowy rząd też spróbuje go wdrożyć (?), http://di.com.pl/elektroniczny-dowod-osobisty-nowy-rzad-tez-sprobuje-go-wdrozyc--53863 (dostęp: 11.09.2016).

58 Nowe e-dowody osobiste najpóźniej w 2019 roku, http://finanse.wp.pl/kat,103 3699, title,Nowe-e-dowody-osobiste-najpozniej-w-2019-roku,wid,18210562, wiadomosc.html?ticaid=117be7 (dostęp: 11.09.2016).

59 Electronic ID Card, https://e-estonia.com/component/electronic-id-card/ (dostęp: 11.09.2016). 
- jako karta ubezpieczenia zdrowotnego,

- jako dowód tożsamości podczas logowania się do kont bankowych $\mathrm{z}$ komputera osobistego,

- jako karta komunikacji miejskiej obsługująca opłaty za transport miejski w systemie pre-paid ${ }^{60} \mathrm{w}$ największych polskich miastach,

- do podpisów cyfrowych,

- do głosowania za pośrednictwem Internetu,

- jako dostęp do rządowych baz danych w celu sprawdzenia swoich danych medycznych, informacji podatkowych itp.,

- do odbierania e-recept.

Wszelkie niezbędne dane potrzebne do pełnienia tylu funkcji mogą być umieszczone na specjalnym chipie zintegrowanym z samą kartą. Wśród zawartych na nim informacji byłyby wszystkie umieszczone fizycznie na e-dowodzie osobistym oprócz zdjęcia i odręcznego podpisu ${ }^{61}$. W przypadku tak istotnego dokumentu i przechowywanych na nim danych chip musi być bezpieczny. Osadzone na nim dane mogą zostać zabezpieczone przy użyciu 2048-bitowego szyfrowania z kluczem publicznym, co umożliwiłoby stosowanie go jako ostatecznego potwierdzenia tożsamości w środowisku elektronicznym ${ }^{62}$. Ponadto karta mogłaby zawierać dwa certyfikaty oraz związane z nimi klucze prywatne, które są chronione kluczem PIN. Mogłyby się na niej również znajdować certyfikaty, które zawierają nazwisko posiadacza oraz indywidualny numer jego e-dowodu. Dodatkowo certyfikat uwierzytelniający posiadałby unikalny adres e-mail posiadacza ${ }^{63}$.

Rysunek 1 przedstawia zestawienie aktualnie obowiązujących dowodów osobistych kolejno w Estonii i Polsce. Można stwierdzić, że oba dokumenty są prawie identyczne, za wyjątkiem obecności w estońskim e-dowodzie chipu, który również znajdzie swoje miejsce na polskim dowodzie osobistym w najbliższej przyszłości.

Oprócz praktyk stosowanych przez Estonię Polska samodzielnie stara się wychodzić naprzeciw oczekiwaniom obywateli i nieustannie zmieniającej się technologii. Minister cyfryzacji Anna Streżyńska zauważa, że w Polsce jest 19 mln smartfonów i każde z tych urząazeń jest w użyciu przez trzy godziny dziennie. Właśnie z tego powodu chce ona stworzyć wielopostaciowy dowód osobisty, który funkcjonowałby również na smartfonach za pośrednictwem mobilnej wersji portalu obywatel.gov.pl, który łączyłby

60 System płatności z góry tożsamy z zasadami funkcjonowania usług telekomunikacyjnych sieci komórkowych „na doładowanie konta”.

61 The Estonian ID Card and digital signature concept. Principles and solutions, http://www.id.ee/public/The_Estonian_ID_Card_and_Digital_Signature_Concept. pdf (dostęp: 11.09.2016).

62 Electronic ID Card, https://e-estonia.com/component/electronic-id-card/ (dostęp: 11.09.2016).

63 The Estonian ID Card... 
Rysunek 1. Porównanie aktualnych dowodów osobistych: estońskiego oraz polskiego

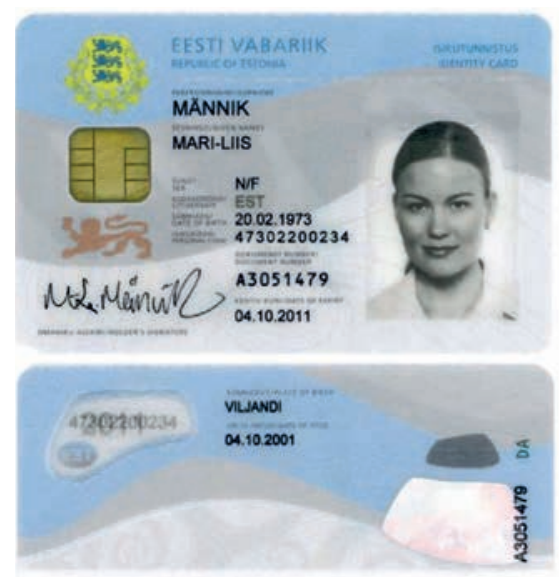

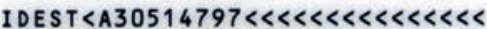
$7302208 \mathrm{~F} 1110045 \mathrm{EST} \ll<\ll<\ll<\ll<\ll<<4$

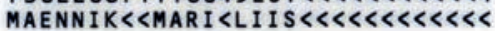
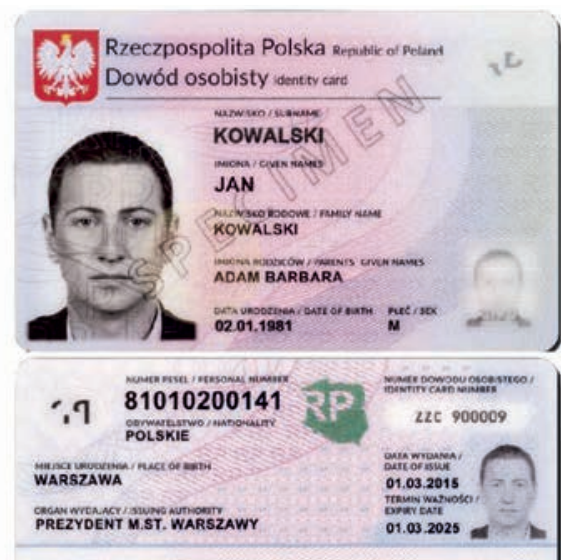

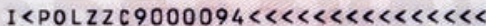
$8101028 M 2501305$ POL 810102001412

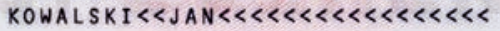

Źródło: The Estonian ID Card...

w całość wszystkie e-usługi w Polsce. Początkowo mówiło się o wprowadzeniu takiej usługi w 2017 r. $^{64}$

\subsection{E-głosowanie i cyberbezpieczeństwo}

Kolejną istotną praktyką, idącą w parze z cyfrowym dowodem osobistym, jest możliwość głosowania za pośrednictwem Internetu. Obecny sposób głosowania wymaga od wyborcy zachowania szczególnej formy, czyli osobistego stawiennictwa w lokalu wyborczym przypisanym na podstawie adresu zameldowania. Dla wielu obywateli, którym przysługuje czynne prawo wyborcze, stwarza to pewne bariery uniemożliwiające oddanie głosu. Dodatkowo tradycyjny sposób głosowania potrafi wykluczyć z całego procesu osoby z niepełnosprawnością ruchową. Udostępniając więc możliwość oddawania głosów w sposób cyfrowy, zmniejsza się wysiłek konieczny do jego oddania, co przekłada się na zwiększenie dostępności i równości wobec obywateli. Dodatkowo w wariancie elektronicznym można wyeliminować oddawanie głosów nieważnych, gdyż zmusza się wyborcę do postawienia „X” w prawidłowym miejscu, czego nie można zagwarantować podczas tradycyjnego głosowania. Najważniejszą zaletą takiego rozwiązania jest przede wszystkim zwiększenie uczestnictwa obywateli i frekwencji

64 W 2017 r. dowody osobiste na smartfonach, http://www.rp.pl/W-sadzie-i-urzedzie/306179967-Strezynska-w-2017-r-dowody-osobiste-na-smartfonach.html\#ap-1 (dostęp: 11.09.2016). 
wyborczej, która od początku przemian systemowych nie była zbyt wysoka, co przedstawia poniższy wykres ${ }^{65}$.

Wykres 4. Frekwencja wyborcza w Polsce po 1989 r. (w procentach)

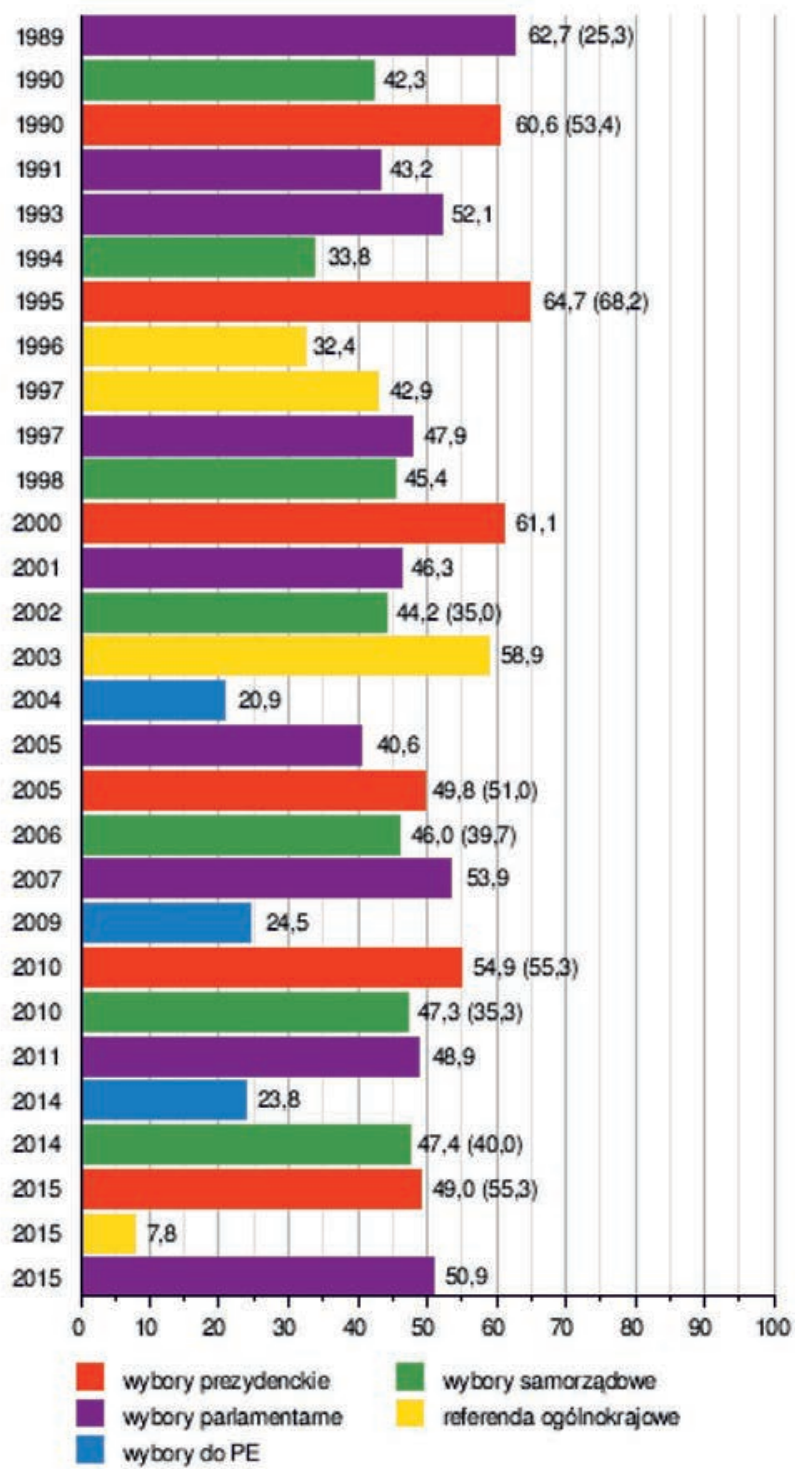

Źródło: Frekwencja wyborcza, https://pl.wikipedia.org/wiki/Frekwencja_wyborcza (dostęp: 11.09.2016)

65 M. Kowalski, Głosowanie przez Internet - dlaczego jeszcze nie w Polsce? Korzyści i zagrożenia związane $z$ wyborami elektronicznymi, http://softonet.pl/publikacje/poradniki/Glosowanie.przez.internet-dlaczego.jeszcze.nie.w.Polsce.Korzysci.i.zagrozenia. zwiazane.z.wyborami.elektronicznymi,1383 (dostęp: 11.09.2016). 
Takie rozwiązania stwarzają również pewne zagrożenia w zakresie bezpieczeństwa. Pomimo braku możliwości e-głosowania w Polsce przy okazji wyborów w 2014 r. doszło do pewnego incydentu. W wyborach samorządowych swoistą pomoc dla komisji stanowić miało oprogramowanie „Kalkulator", odpowiedzialne za generowanie potwierdzeń oraz przesyłanie protokołów, a ostatecznie za podliczanie głosów. Niestety projekt nie został zrealizowany z należytą starannością i umożliwił każdemu zainteresowanemu pobranie go z Internetu oraz swobodne wpływanie na funkcjonowanie samego systemu ${ }^{66}$. Ostateczne ogłoszenie wyników spowodowane nieprawidłowym funkcjonowaniem systemu nastąpiło z zauważalnym opóźnieniem ${ }^{67}$. Przyjęcie estońskiej praktyki dbałości o cyberbezpieczeństwo mogłoby pozwolić na ograniczenie występowania tego typu incydentów w przyszłości.

\section{Podsumowanie}

Pomimo dużych nakładów finansowych przeznaczonych na rozwój elektronicznych usług administracji publicznej, w Polsce wciąż brakuje spójnej struktury. Większość projektów rozpoczynanych przed laty do tej pory nie zostało zrealizowanych, a te które udało się zakończyć, pozostawiają wiele do życzenia. Dostrzegalny jest brak płynności podczas ich realizacji, często prace zostają wstrzymane, czego efektem jest odkładanie ich w czasie. Dodatkowo obywatele nie są świadomi oferowanych usług lub nie potrafią z nich korzystać, przez co preferują tradycyjne metody komunikacji z administracją publiczną. Istnieje także obawa o bezpieczeństwo danych przechowywanych i przetwarzanych przez systemy informatyczne.

Mimo że Polska i Estonia zaczynały wprowadzać rozwiązania e-administracji w tym samym czasie, Estonii udało się to osiągnąć znacznie szybciej, skuteczniej i przy użyciu niższych nakładów finansowych. Żeby Polska mogła skutecznie przyjąć dobre praktyki e-administracji od Estonii, powinna sprostać następującym wyzwaniom ${ }^{68}$ :

- porzucenie papieru i pieczątki. W mentalności urzędników głęboko zakorzenione są fizyczne wersje dokumentów, które przedkładają w kwestii ważności nad ich cyfrowe odpowiedniki,

- brak jednolitego pomysłu na e-administrację oraz brak koordynacji. Upłynęło bardzo dużo czasu i wydano znaczące ilości pieniędzy na co-

66 ProblemywPKW.Zliczaniegłosówwyborcówsięopóźnia-zawiódłsysteminformatyczny, https://niebezpiecznik.pl/post/problemy-w-pkw-zliczanie-glosow-wyborcowsie-opoznia-zawiodl-system-informatyczny/?xPTR1 (dostęp: 11.09.2016).

67 Wyniki wyborów opóźnione? PKW ma kłopoty z systemem informatycznym, http://wiadomosci.dziennik.pl/wybory-samorzadowe/artykuly/475289, wybory-samorzadowe-pkw-ma-klopoty-z-systemem-informatycznym.html (dostęp: 11.09.2016).

68 Grzechy e-administracji, http://www.u24.pl/grzechy-e-administracji/ (dostęp: 11.09.2016). 
raz to nowsze koncepcje. Sytuacja wydaje się być bardziej stabilna od momentu utworzenia Ministerstwa Administracji i Cyfryzacji,

- cyfrowe wykluczenie osób. Dla wielu Polaków problemem jest już sam brak dostępu do Internetu, co wynika z nieistnienia infrastruktury w wielu rejonach kraju. Po wyeliminowaniu tej bariery można by wprowadzić edukację dotyczącą informatyzacji i przedstawić Internet jako przydatne narzędzie,

- promocja i atrakcyjność e-usług. Należy zwrócić uwagę na przydatność oferowanych e-usług oraz na informowanie o nich. Polacy oczekują usług, które ułatwiłyby im funkcjonowanie, w miejscach, w których pojawiają się o wiele częściej niż w urzędach, czyli np. w przychodniach.

Mimo opisanych problemów należy patrzeć na cyfrową przyszłość Polski z optymizmem. Błędy są diagnozowane. Konstruktywne wnioski oraz dobre praktyki zaczerpnięte od państw wysoce rozwiniętych pod względem e-usług stanowią dobry początek dla nowatorskich i nieszablonowych rozwiązań.

\section{Bibliografia}

Chlewicki M., Kędzierska A., Oranowski M., Elektroniczna administracja w Estonii, http://www.bibliotekacyfrowa.pl/Content/34511/016.pdf.

Człowiek $i$ dokumenty - Stare, nowe i najnowsze... dowody osobiste - uwagi nie tylko pochlebne, http://ww1.pwpw.pl/kwartalnik_archiwum.html?id=26\&magCid=29.

Dzierżek A., Cud technologiczny na północy Europy. Jak Estonia stała się internetowa potega i państwem bez granic, http://forsal.pl/artykuly/865849,cud-technologiczny-na-polnocy-europy-jak-estonia-stala-sie-internetowa-potega-i-panstwem-bez-granic.html.

Electronic ID Card, https://e-estonia.com/component/electronic-id-card/.

ePolska. Plan działań na rzecz rozwoju społeczeństwa informacyjnego w Polsce na lata 2001-2006. Dostęp 05.09.2016, http://kbn.icm.edu.pl/cele/epolska.doc.

Estonia dzieli się swoim e-doświadczeniem, http://newsrm.tv/komunikat-pr/estonia-dzieli-sie-swoim-e-doswiadczeniem/.

Estonia w Unii Europejskiej, https://europa.eu/european-union/about-eu/countries/member-countries/estonia_pl.

Golański A., E-stonia, czyli jak Estonia zrobiła pierwszy krok ku dobrowolnemu państwu bez granic, http://www.dobreprogramy.pl/Estonia-czyli-jak-Estonia-zrobila-pierwszy-krok-ku-dobrowolnemu-panstwu-bez-granic,News,60578. html.

Grodzka D., E-administracja w Polsce, http://orka.sejm.gov.pl/WydBAS.nsf/0/5B3 DCD2263623C69C125730E003F93CA/\$file/infos_018.pdf.

Grodzka D., E-governemnt in Poland, http://orka.sejm.gov.pl/WydBAS.nsf/0/9BBD52682ADC88EEC1257A30003C8B7F/\$file/3_19.pdf.

Grzechy e-administracji, http://www.u24.pl/grzechy-e-administracji/. 
Komisja Europejska Polska, E-administracja jest OK, http://ec.europa.eu/polska/ news/130528_e_administracja_pl.htm.

Kowalski M., Głosowanie przez Internet - dlaczego jeszcze nie w Polsce? Korzyści i zagrożenia związane $z$ wyborami elektronicznymi, http://softonet.pl/publikacje/poradniki/Glosowanie.przez.internet-dlaczego.jeszcze.nie.w.Polsce.Korzysci.i.zagrozenia.zwiazane.z.wyborami.elektronicznymi,1383.

Kozłowska B., Miejsce dla obywateli: e-administracja, Fundacja Rozwoju Społeczeństwa Informatycznego: Warszawa 2010, http://programrozwojubibliotek. org/wp-content/uploads/2015/07/Miejsce_dla_obywateli_e_administracja. pdf.

Kutyłowski M., Zagórski F., Głosowanie elektroniczne. Aktualny stan wiedzy, http:// klub.platforma.org/files/raport.pdf.

Maj M., Elektroniczny dowód osobisty - nowy rząd też spróbuje go wdrożyć (?), http://di.com.pl/elektroniczny-dowod-osobisty-nowy-rzad-tez-sprobuje-go-wdrozyc--53863.

Nixon P.G., Koutrakou V.N., E-government in Europe. Re-booting the state, Routledge, Canada 2007.

NIK o usługach elektronicznych $w$ administracji publicznej, https://www.nik.gov.pl/ aktualnosci/nik-o-uslugach-elektronicznych-w-administracji-publicznej.html.

Nowee-dowody osobiste najpóźniej w 2019 roku, http://finanse.wp.pl/kat,1033699,title,Nowe-e-dowody-osobiste-najpozniej-w-2019-roku,wid,18210562, wiadomosc.html?ticaid=117be7.

Nowy dowód osobisty - PWPW przygotowała 27 tys. Plakatów informacyjnych, https://mswia.gov.pl/pl/aktualnosci/12966, Nowy-dowod-osobisty-PWPW-przygotowala-27-tys-plakatow-informacyjnych.html.

Olejak K., E-państwo po estońsku, http://jagiellonski24.pl/2016/02/02/e-panstwo-po-estonsku/.

Pappel I., Vanker E., Przegląd projektów e-Government w Estonii, http://egov2.eu/ $\mathrm{pl} /$ knowledge-base/przeglad-projektow-e-government-w-estonii/.

Polska $w$ drodze do społeczeństwa informacyjnego, http://e-administracja.net/e-administracja/polska-w-drodze-do-spoleczenstwa-informacyjnego.

Polska w Unii Europejskiej, https://europa.eu/european-union/about-eu/countries/ member-countries/poland_pl.

Popławski K., I-wybory. E-wybory. Wybory on-line. A gdybyśmy uważniej spojrzeli na Estonię?, https://wszystkoconajwazniejsze.pl/kazimierz-poplawski-i-wybory-e-wybory-wybory-on-line-a-gdybysmy-uwazniej-spojrzeli-na-estonie/.

Problemy w PKW. Zliczanie głosów wyborców się opóźnia - zawiódt system informatyczny, https://niebezpiecznik.pl/post/problemy-w-pkw-zliczanie-glosow-wyborcow-sie-opoznia-zawiodl-system-informatyczny/?xPTR1.

Ratajczak M., E-administracje w Polsce kosztowała miliardy złotych. I wciąż jest gorsza niż w Rosji i Kazachstanie, http://news.money.pl/artykul/e-administracja-w-polsce-kosztowala-miliardy,48,0,1755184.html.

Statistical Office of Estonia, http://www.stat.ee/population.

Sudaj K., O kłopotach z nowym dowodem osobistym bez adresu zameldowania, http://www.bankier.pl/wiadomosc/O-klopotach-z-nowym-dowodem-osobistym-bez-adresu-zameldowania-7239103.html. 
Szubert K., E-administracja w Polsce: korzyści i koszty, http://www.egospodarka. $\mathrm{pl} / 117769$, E-administracja-w-Polsce-korzysci-i-koszty,1,39,1.html.

The Estonian ID Card and Digital Signature Concept. Principles and Solutions, http://www.id.ee/public/The_Estonian_ID_Card_and_Digital_Signature_ Concept.pdf.

W 2017 r. dowody osobiste na smartfonach, http://www.rp.pl/W-sadzie-i-urzedzie/306179967-Strezynska-w-2017-r-dowody-osobiste-na-smartfonach.html\#ap-1.

Wyniki wyborów opóźnione? PKW ma kłopoty z systemem informatycznym, http:// wiadomosci.dziennik.pl/wybory-samorzadowe/artykuly/475289,wybory-samorzadowe-pkw-ma-klopoty-z-systemem-informatycznym.

\section{Streszczenie}

W świecie daleko idącej globalizacji i gwałtownego rozwoju technologii informacyjnych cyfryzacja administracji publicznej wydaje się nieuchronnym zjawiskiem niosącym korzyści zarówno dla samej administracji sensu largo, jak i jej klientów. W chwili przystąpienia Polski do Unii Europejskiej proces ten nasilił się ze względu na wyznaczone standardy europejskie. Do podobnych działań została zmuszona Estonia, która w tym samym czasie co Polska wstąpiła w struktury Unii Europejskiej. Po upływie lat zauważa się znaczące różnice między tymi państwami w rozwoju cyfrowej administracji publicznej. Estonia w stosunkowo krótkim czasie oraz przy ograniczonych nakładach finansowych stała się jednym $z$ najbardziej scyfryzowanych państw w Europie. W związku z tym Polska powinna inspirować się estońską praktyką we wdrażaniu e-administracji na rodzimym rynku.

Słowa kluczowe: administracja publiczna, e-administracja, elektroniczne usługi, Estonia, Polska

\section{Good Practice in Estonian E-Government: Recommendations for Poland}

Abstract

In the world of far-reaching globalisation and the rapid development of information technology, digitisation of the public sector seems to be inevitably benefiting both administration as a whole and its customers. At the time of Poland's accession to the European Union, the process intensified due to the standards set by the EU. A similar action was taken by Estonia which joined the European Union at the same time as Poland. Over the years, there have been significant differences between these countries in the development of digital public administration. Estonia, in a relatively short period and with limited financial resources, has become one of the most digital countries in Europe. Thus, Poland should be inspired by Estonian practice as regards the implementation of eGovernment.

Keywords: electronic services, e-government, Estonia, Poland, public administration 